\title{
Metabolism of Circulating Disaccharides in Man and the Rat*
}

\author{
Elliot Weser $†$ and Marvin H. Sleisenger $\$$ With the technical assistance \\ of Marjorie Dickstein and Fitz. H. Bartley
}

(From the Division of Gastroenterology, Department of Medicine, Cornell University Medical College, New York, N. Y.)

\begin{abstract}
Summary. The metabolism of circulating disaccharides was studied in adult humans and rats. After iv infusions of $10 \mathrm{~g}$ of either lactose, sucrose, or maltose in four adults, no rise in blood glucose was noted. A mean of $8.7 \pm$ $1.89 \mathrm{~g}$ of the lactose and $6.3 \pm 1.39 \mathrm{~g}$ of the sucrose was excreted in the 24-hour urine sample. Only $0.11 \pm 0.03 \mathrm{~g}$ of the infused maltose was recovered in the urine, suggesting that the maltose was metabolized.

After injection of ${ }^{14} \mathrm{C}$-labeled lactose and sucrose in rats, $6.2 \pm 2.7$ and 7.6 \pm $2.4 \%$, respectively, was oxidized to ${ }^{14} \mathrm{CO}_{2}$ in 24 hours; $62.1 \pm 13.5$ and $68.4 \pm$ $10.8 \%$ of the respective disaccharides was excreted into the urine. Conversely, after injection of ${ }^{14} \mathrm{C}$-labeled maltose $54.6 \pm 7.0 \%$ was oxidized to ${ }^{14} \mathrm{CO}_{2}$ and $4.8 \pm 3.9 \%$ excreted in the urine. The per cent of maltose oxidized to $\mathrm{CO}_{2}$ was similar to that of glucose.

In addition to small intestinal mucosa, homogenates of rat kidney, brain, and liver as well as serum were found to have measurable maltase activities. The role of these tissue maltases in the metabolism of circulating maltose and maltosyloligosaccharides is discussed.
\end{abstract}

\section{Introduction}

The hydrolysis of disaccharides by disaccharidases in the intestinal mucosa is usually so complete that only a small fraction of the ingested disaccharide is absorbed intact and excreted in the urine $(1,2)$. An increase in the absorption and urinary excretion of unhydrolyzed lactose and sucrose has been reported in patients with celiac disease $(3,4)$, tropical sprue $(5,6)$, and a variety of other gastrointestinal disorders $(4,7-9)$ usually associated with a deficiency of intestinal disaccharidases. The purpose of the present study was to compare the metabolic fate of circulating lac-

* Submitted for publication September 29, 1966; accepted December '8, 1966.

Supported by grants from the New York City Health Research Council (1-288 and U-1573) and the John A. Hartford Foundation.

† Current address: University of Texas South Texas Medical School, San Antonio, Texas.

¥Address requests for reprints to Dr. Marvin H. Sleisenger, New York Hospital, 525 E. 68th St., New York, N. Y. 10021. tose, sucrose, and maltose in adult humans and rats. The results suggest that circulating maltose, unlike lactose and sucrose, may be hydrolyzed by extraintestinal maltases and subsequently metabolized.

\section{Methods}

Studies in man. Normal individuals and patients with untreated celiac disease fasted overnight and, after voiding, ingested $25 \mathrm{~g}$ of either lactose, sucrose, or maltose in $500 \mathrm{ml}$ of water. All urine was collected for the next 5 hours and a sample frozen for subsequent assay. Urinary disaccharides were determined by incubating 0.1 $\mathrm{ml}$ of desalted urine (10) with $1 \mathrm{mg}$ of commercial lactase, sucrase, or maltase dissolved in $0.2 \mathrm{ml}$ of appropriate buffer for 1 hour at $37^{\circ} \mathrm{C}$. The buffer for lactase was $0.35 \mathrm{M}$ sodium phosphate, $\mathrm{pH} 7.25$; for sucrase, $0.05 \mathrm{M}$ sodium acetate, $\mathrm{pH} 4.77$; and for maltase, $0.05 \mathrm{M}$ sodium acetate, pH 5.20. After incubation, the net increase in glucose was measured by the glucose oxidase method (11) and used to calculate the amount of disaccharide present in the urine. Experiments with standard disaccharide solutions yielded a 90 to $95 \%$ recovery.

Four adult subjects were given iv infusions of $10 \mathrm{~g}$ in $100 \mathrm{ml}$ of water of either lactose, sucrose, or maltose 


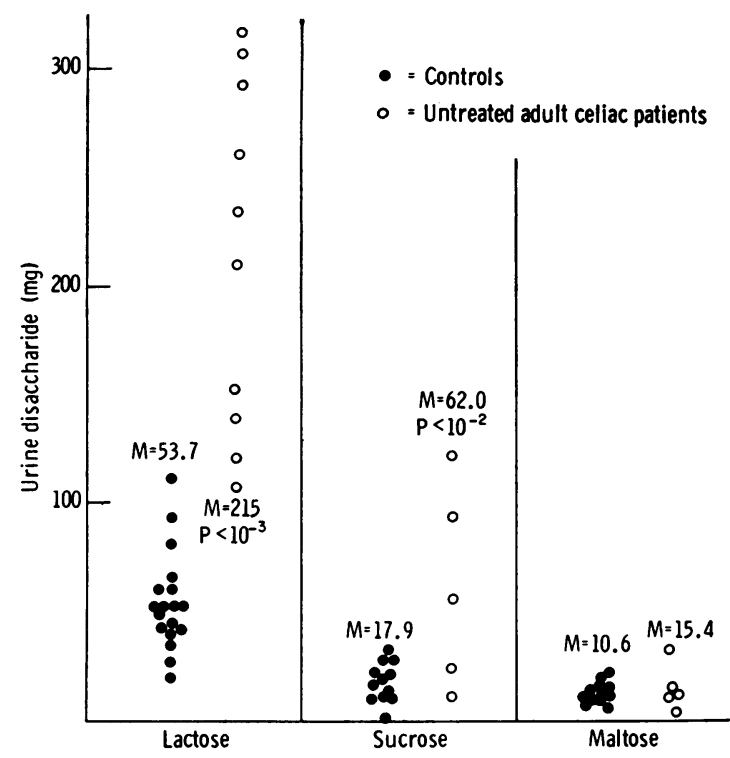

Fig. 1. Disaccharide RECOVERED IN 5-Hour URINE SAMPLE AFTER INGESTION OF 25 G OF LACTOSE, SUCROSE, OR MALTOSE. $\mathrm{M}=$ mean.

over a 30-minute period. Blood was collected at 0,15 , $30,60,90,120,150$, and 180 minutes, and urine was collected under refrigeration for 24 hours. Blood sugar (12), true blood glucose (11), and urinary disaccharides were determined.

In vivo studies in rats. Experiments were performed on nonfasting male Sprague-Dawley rats weighing approximately $250 \mathrm{~g}$ and fed a standard ad libitum diet.1 Five mg of either lactose, sucrose, maltose, or appropriate monosaccharides dissolved in $0.5 \mathrm{ml}$ of water was injected into the tail vein. Each injection contained $0.5 \mu \mathrm{c}$ of the respective ${ }^{14} \mathrm{C}$-labeled disaccharide or monosaccharide. ${ }^{2}$ Radiopurity of the ${ }^{14} \mathrm{C}$-labeled sugars was verified by descending paper chromatography and found to be greater than $98 \%$. Before injection, some animals were anesthetized with ether and underwent either complete resection of the small bowel, bilateral nephrectomy, 70\% hepatectomy, or a sham operation. After injection the rats were placed in a metabolic chamber, and the $\mathrm{CO}_{2}$ expired over a 24-hour period was assayed according to the method of Fredrickson and Ono (13). ${ }^{14} \mathrm{CO}_{2}$ in Hyamine was assayed in a Packard liquid scintillation spectrometer at $90 \%$ efficiency. Urine was also collected under refrigeration for 24 hours for determination of radioactivity. Quenching was corrected by the channels ratio method (14).

1 Rockland mouse/rat diet, distributed by Tekland, Monmouth, I11.

${ }^{2}$ Lactose- $1-{ }^{14} \mathrm{C}$, sucrose-U- ${ }^{14} \mathrm{C}$, maltose- $1-{ }^{14} \mathrm{C}$, glucose$1-{ }^{14} \mathrm{C}$, glucose- $\mathrm{U}-{ }^{14} \mathrm{C}$, galactose- $1-{ }^{14} \mathrm{C}$, and fructose $-1-{ }^{14} \mathrm{C}$ were obtained from Calbiochem, Los Angeles, Calif. Maltose-U- ${ }^{14} \mathrm{C}$ was obtained from Nuclear-Chicago, Des Plaines, Ill.
Urine was desalted by stirring with Rexyn 1-300 $(\mathrm{H}-\mathrm{OH})^{3}$ and then subjected to descending paper chromatography on Whatman 1 filter paper for 16 hours. The solvent systems were a) butanol, ethanol, and water $(40: 10: 50$, lower phase) and $b)$ isopropanol and water $(160: 40)$. The dried chromatograms were cut into strips and radioactive peaks detected by a Vanguard automatic chromatogram scanner. Glucose- $1-{ }^{14} \mathrm{C}$ and appropriate ${ }^{14} \mathrm{C}$-labeled disaccharides were used as reference compounds and the migration distances calculated as $\mathrm{Rg}$ [ (distance sugar travels from the origin/distance glucose travels from the origin) $\times 100]$.

In other experiments the jugular vein of rats was cannulated under light Pentothal anesthesia, and $100 \mathrm{mg}$ of either lactose, sucrose, or maltose in $0.5 \mathrm{ml}$ of water was infused over a 5-minute period. Glucose was measured in blood collected from the tail at $0,5,15,30,45$, and 60 minutes (11).

In vitro studies in rats. Experiments to determine maltase content of various organs were performed in nonfasting male Sprague-Dawley rats weighing approximately $250 \mathrm{~g}$. The rats were stunned by a blow on the head and exsanguinated by decapitation. Tissue slices from liver, kidney, and brain were prepared with a Stadie-Riggs tissue slicer. Triplicate incubations were carried out in 25-ml Erlenmeyer flasks containing $2.5 \mathrm{ml}$ Krebs-Henseleit bicarbonate buffer, pH 7.4 (15), $5 \mathrm{mg}$ of disaccharide or monosaccharide, and $0.5 \mu \mathrm{c}$ of ${ }^{14} \mathrm{C}-$ labeled disaccharides or monosaccharides. After being gassed with $95 \% \quad \mathrm{O}_{2}$ and $5 \% \quad \mathrm{CO}_{2}$ for 10 seconds, the flasks were capped with serum stoppers fitted with a center well. The incubations were carried out in a Dubnoff shaking incubator for 1 hour at $37^{\circ} \mathrm{C}$. At the end of this time, $0.5 \mathrm{ml}$ of $1 \mathrm{M}$ Hyamine was injected through the serum stopper into the center well, and $0.3 \mathrm{ml}$ of $6 \mathrm{M}$ sulfuric acid was similarly added to the incubation mixture. The flasks were then incubated for an additional 45 minutes at $37^{\circ} \mathrm{C}$ to permit diffusion of the liberated ${ }^{14} \mathrm{CO}_{2}$ into the hyamine. The Hyamine in the center well was then transferred quantitatively to $20-\mathrm{ml}$ counting vials, and $14 \mathrm{ml}$ of a solution of $0.3 \%$ 2,5,-diphenyloxazole and $0.01 \%$ 1,4-bis-2-(5-phenyloxazolyl) benzene in toluene was added. Radioactivity of the ${ }^{14} \mathrm{CO}_{2}$ was counted in a liquid scintillation spectrometer as described above.

Organ homogenates were prepared by homogenizing $1 \mathrm{~g}$ of tissue with $4 \mathrm{ml}$ of chilled distilled water in a Potter-Elvehjem tissue grinder. Maltase activity in whole homogenates diluted $1: 50$ or $1: 100$ was measured according to the method of Sols and De la Fuente (16). Protein was determined by the method of Lowry, Rosebrough, Farr, and Randall (17). One U of maltase activity was equal to $1 \mu$ mole of maltose hydrolyzed per minute per $\mathrm{g}$ of tissue protein.

\section{Results}

Studies in man. Normal subjects ingested $25 \mathrm{~g}$ of lactose, sucrose, or maltose and excreted

${ }^{3}$ Fisher Scientific Co., New York, N. Y. 
TABLE I

Disaccharide recovered in 24-hour urine sample after iv administration of $10 \mathrm{~g}$ in adult humans

\begin{tabular}{cccc}
\hline & \multicolumn{3}{c}{ Disaccharide infused } \\
\cline { 2 - 4 } Subject & Lactose & Sucrose & Maltose \\
\hline & $g$ & $g$ & $g$ \\
J.S. & 10.5 & 7.2 & 0.09 \\
I.R. & 7.1 & & 0.08 \\
B.B. & 8.6 & 4.8 & 0.12 \\
B.G. & & 6.8 & 0.15 \\
Mean \pm SD & $8.7 \pm 1.8$ & $6.3 \pm 1.3$ & $0.11 \pm 0.03$ \\
\hline
\end{tabular}

(mean \pm SD) $53.7 \pm 22.8,17.9 \pm 9.6$, and $10.6 \pm$ $2.1 \mathrm{mg}$, respectively, in the 5-hour urine sample (Figure 1). After lactose and sucrose ingestion, $215 \pm 80(p<0.001)$ and $62.0 \pm 49(p<0.01)$ $\mathrm{mg}$, respectively, was excreted by patients with untreated celiac disease (Figure 1). This amount was a fourfold increase of urinary disaccharide excretion over normal and suggested enhanced intestinal absorption of unhydrolyzed lactose and sucrose. After maltose ingestion celiac patients excreted a mean of $15.4 \pm 10.6 \mathrm{mg}$, not significantly different from the controls $(0.3>\mathrm{p}>$ 0.25 ).

These findings suggested that, unlike lactose or sucrose, the intestinal absorption of unhydrolyzed maltose was either not increased in celiac disease or its metabolic fate was different from that of the other disaccharides. To study this further, we measured the concentration of blood sugar after the infusion of $10 \mathrm{~g}$ of lactose, sucrose, or maltose in four adult subjects. As shown in Figure 2, copper-reducing substance rose after iv lactose and maltose, reflecting the increase in circulating disaccharide (sucrose is not a copper-reducing

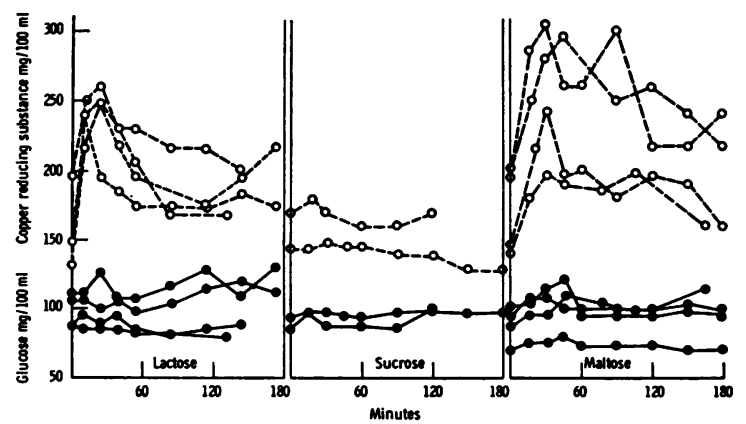

Fig. 2. NONSPECIFIC COPPER-REDUCING SUBSTANCE AND TRUE BLOOD GLUCOSE CONCENTRATION AFTER IV INFUSION OF 10 G OF LACTOSE, SUCROSE, OR MALTOSE IN ADULT HUMANS.

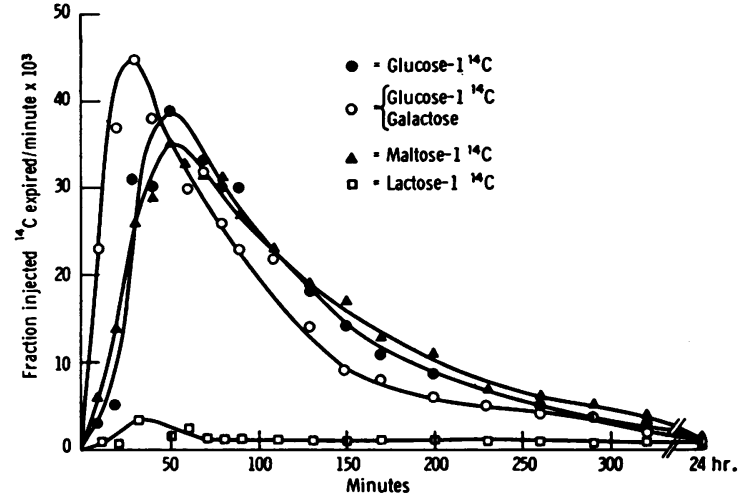

Fig. 3. Oxidation of $1-{ }^{14} \mathrm{C}$-labeled disaccharide to ${ }^{14} \mathrm{CO}_{2}$ AFTER IV INJECTION IN THE RAT. Each curve represents mean of five animals.

sugar). No significant increase in true blood glucose was noted after any of the disaccharide infusions. A mean of $8.7 \pm 1.8 \mathrm{~g}$ of the lactose and $6.3 \pm 1.3 \mathrm{~g}$ of the sucrose was excreted in the 24-hour urine sample (Table I). In contrast, only $0.11 \pm 0.03 \mathrm{~g}$, or $1 \%$, of the infused maltose was excreted into the urine.

Studies in the rat. After the iv injection of lactose-1-14 C (Figure 3 ), or sucrose-U-14 $\mathrm{C}$, only small amounts of isotope appeared in the expired $\mathrm{CO}_{2}$ over a 24-hour period. On the other hand, after maltose- $1-{ }^{14} \mathrm{C}$ or maltose-U- ${ }^{14} \mathrm{C}$ injection, excretion of the isotope as ${ }^{14} \mathrm{CO}_{2}$ was rapid, comparable to that found after the injection of glucose${ }^{1-14} \mathrm{C}$ or other monosaccharide mixtures. These monosaccharides were selected because they are the hydrolytic metabolites of the injected disaccharides. Peak ${ }^{14} \mathrm{CO}_{2}$ excretion after maltose-1${ }^{14} \mathrm{C}$ was noted between 50 and 70 minutes after injection.

The results of the metabolism of disaccharides are summarized in Table II. After lactose- $1{ }^{14} \mathrm{C}$ and sucrose-U- ${ }^{14} \mathrm{C}$ injection (mean $\pm \mathrm{SD}$ ), $6.2 \pm$ 2.7 and $7.6 \pm 2.4 \%$, respectively, was oxidized to ${ }^{14} \mathrm{CO}_{2}$ in 24 hours ; $62.1 \pm 13.5$ and $68.4 \pm 10.8 \%$ of the respective disaccharide was excreted into the urine. After the injection of maltose- $1-{ }^{14} \mathrm{C}$ and maltose-U- ${ }^{14} \mathrm{C}, 54.6 \pm 7.0$ and $58.6 \pm 5.8 \%$, respectively, was oxidized to ${ }^{14} \mathrm{CO}_{2}$ and only $4.8 \pm$ 3.9 and $3.2 \pm 3.0 \%$, respectively, was excreted in the urine. The per cent of maltose $-{ }^{14} \mathrm{C}$ oxidized to ${ }^{14} \mathrm{CO}_{2}$ was similar to that of ${ }^{14} \mathrm{C}$-labeled monosaccharides. 
TABLE II

Metabolism of ${ }^{14} \mathrm{C}$-labeled disaccharides after iv administration in the rat*

\begin{tabular}{|c|c|c|c|}
\hline Sugar & $\begin{array}{c}\text { No. } \\
\text { animals }\end{array}$ & ${ }^{14} \mathrm{CO}_{2}$ & Urine ${ }^{14} \mathrm{C}$ \\
\hline & & \multicolumn{2}{|c|}{$\%$ dose $/ 24$ hours } \\
\hline Glucose-1-14C & 5 & $62.0 \pm 11.6$ & $5.3 \pm 4.7$ \\
\hline Glucose-U-14 C & 5 & $64.0 \pm 12.0$ & $14.8 \pm 10.3$ \\
\hline Glucose $-1-{ }^{14} \mathrm{C}+$ & & & \\
\hline $\begin{array}{l}\text { galactose } \\
\text { Glucose-U-14 } \mathrm{C}+\end{array}$ & 4 & $52.0 \pm 9.7$ & $9.8 \pm 6.6$ \\
\hline fructose-U-14 $\mathrm{C}_{\ddagger}^{+}$ & 5 & $50.7 \pm 7.9$ & $19.3 \pm 4.6$ \\
\hline Maltose-1-14 C & 5 & $54.6 \pm 7.0$ & $4.8 \pm 3.9$ \\
\hline Maltose-U- ${ }^{14} \mathrm{C}$ & 5 & $58.6 \pm 5.8$ & $3.2 \pm 3.0$ \\
\hline Lactose $-1-{ }^{14} \mathrm{C}$ & 6 & $6.2 \pm 2.7$ & $62.1 \pm 13.5$ \\
\hline Sucrose-U-14C & 5 & $7.6 \pm 2.4$ & $68.4 \pm 10.8$ \\
\hline
\end{tabular}

* Animals received $5 \mathrm{mg}$ of sugar in $0.5 \mathrm{ml}(1 \mu \mathrm{c}$ per $\mathrm{ml})$. $\dagger$ Mixture contained $2.5 \mathrm{mg}$ of each sugar and $0.5 \mu \mathrm{c}$ glucose-1-14 $\mathrm{C}$.

$\ddagger$ Mixture contained $2.5 \mathrm{mg}$ and $0.25 \mu \mathrm{c}$ of each sugar.

Paper chromatography of the urinary ${ }^{14} \mathrm{C}$ recovered after injection of each of the disaccharides revealed compounds with $\mathrm{Rg}$ values similar to the injected disaccharide. In addition, after maltose injection, 5 to $10 \%$ of the urinary ${ }^{14} \mathrm{C}$ migrated with an $\mathrm{Rg}$ similar to glucose.

The extensive metabolism of injected maltose to $\mathrm{CO}_{2}$ suggested that tissue other than small bowel mucosa might possess maltase activity; therefore, the maltase activity in homogenates of organs from three rats was measured (Table III). As expected, maltase activity in small bowel mucosa was high; however, kidney, and, to a lesser extent, brain, pancreas, and liver also had measurable maltase levels. Rat serum likewise demonstrated enzyme activity, whereas human serum assayed for comparison had virtually none.

TABLE III

Maltase activity in homogenates of rat organs

\begin{tabular}{lrrr}
\hline \multirow{2}{*}{ Organ } & \multicolumn{3}{c}{ Maltase } \\
\cline { 2 - 4 } & \multicolumn{1}{c}{$\mathbf{1}$} & 2 & 3 \\
\hline & $\mathrm{U}^{*}$ & $\mathrm{U}$ & $\mathrm{U}$ \\
Intestinal mucosa & 485 & 390 & 205 \\
Kidney & 17 & 61 & 73 \\
Brain & 14 & & 4.0 \\
Liver & 2 & 1.6 & 1.7 \\
Pancreas & 1 & 4 & 5.6 \\
Spleen & 0.1 & 0.1 & 0.2 \\
Muscle & 9.1 & 12.5 & 0.3 \\
Serum & 0.3 & 0.1 & 0.2 \\
Human serum & & & \\
\hline
\end{tabular}

* One U equals $1 \mu$ mole maltose hydrolyzed per minute per $g$ protein.
TABLE IV

Oxidation of ${ }^{14} \mathrm{C}$-labeled disaccharides* to ${ }^{14} \mathrm{CO}_{2}$ by rat organ slices

\begin{tabular}{|c|c|c|c|c|}
\hline \multirow{2}{*}{$\begin{array}{l}\text { Experi- } \\
\text { ment } \\
\text { no. }\end{array}$} & \multirow[b]{2}{*}{ Sugar } & \multicolumn{3}{|c|}{${ }^{14} \mathrm{CO}_{2} \dagger$} \\
\hline & & Liver & Kidney & Brain \\
\hline & & \multicolumn{3}{|c|}{ cpm!'g tissue } \\
\hline 1 & $\begin{array}{l}\text { Glucose-1-14C } \\
\text { Maltose-1-14C }\end{array}$ & $\begin{array}{r}32,000 \\
9,000\end{array}$ & $\begin{array}{r}105,000 \\
58,900\end{array}$ & $\begin{array}{l}288,666 \\
110,066\end{array}$ \\
\hline 2 & $\begin{array}{l}\text { Glucose-1-14 } \mathrm{C}+ \\
\text { galactose } f \\
\text { Lactose-1-14 } \mathrm{C}\end{array}$ & $\begin{array}{r}45,930 \\
3,000\end{array}$ & $\begin{array}{r}243,300 \\
15,000\end{array}$ & \\
\hline 3 & $\begin{array}{l}\text { Glucose-U-14 } \mathrm{C}+ \\
\text { fructose-U- }{ }^{14} \mathrm{C} \S \\
\text { Sucrose-U-U-14 } \mathrm{C}\end{array}$ & $\begin{array}{r}45,000 \\
4,330\end{array}$ & $\begin{array}{r}362,000 \\
37,000\end{array}$ & \\
\hline
\end{tabular}

* Five mg containing $0.5 \mu \mathrm{c}$ in each flask.

$\dagger$ Mean of triplicate experiments.

$\ddagger$ Flask contained $2.5 \mathrm{mg}$ of each sugar and $0.5 \mu \mathrm{c}$ glucose- $1-14 \mathrm{C}$.

$\S$ Flask contained $2.5 \mathrm{mg}$ and $0.25 \mu \mathrm{c}$ of each sugar.

Tissue slices were prepared from some of the organs having maltase activity and were incubated with either ${ }^{14} \mathrm{C}$-labeled disaccharide or a control mixture of ${ }^{14} \mathrm{C}$-labeled monosaccharides. The amount of ${ }^{14} \mathrm{CO}_{2}$ produced by liver, kidney, and brain slices during incubation with maltose- $1-{ }^{14} \mathrm{C}$ was 30,56 , and $40 \%$, respectively, of the amount recovered from the incubation with glucose- $1-{ }^{14} \mathrm{C}$ (Table IV). The amount of ${ }^{14} \mathrm{CO}_{2}$ recovered from the incubation of lactose- $1-{ }^{14} \mathrm{C}$ and sucrose$\mathrm{U}-{ }^{14} \mathrm{C}$ with liver and kidney slices was about $10 \%$ or less of that recovered after incubation with the respective control monosaccharides. This was in agreement with negligible lactase and sucrase measurement in those tissues. It would appear that organs containing maltase activity are capable of utilizing maltose in vitro as a substrate for metabolism to $\mathrm{CO}_{2}$.

In an effort to determine whether any one of these organs was responsible for the hydrolysis and subsequent metabolism of circulating maltose, we performed experiments on partially eviscerated animals. The selective removal of either the kidneys, $70 \%$ of the liver, or entire small bowel had little effect on the oxidation of injected maltose${ }^{1-{ }^{14}} \mathrm{C}$ to ${ }^{14} \mathrm{CO}_{2}$ (Table $\mathrm{V}$ ). The effect on the oxidation of injected glucose- $1-{ }^{14} \mathrm{C}$ and lactose$1{ }^{14} \mathrm{C}$ is shown for comparison. After removal of the kidneys, the oxidation of injected lactose $-1-{ }^{14} \mathrm{C}$ to ${ }^{14} \mathrm{CO}_{2}$ increased fivefold.

The presence of serum maltase activity sug- 
TABLE $V$

Oxidation of ${ }^{14} \mathrm{C}$-labeled sugars to ${ }^{14} \mathrm{CO}_{2}$ after iv injection in. partially eviscerated rats

\begin{tabular}{llcr}
\hline \hline \multirow{2}{*}{$\begin{array}{c}\text { Organ } \\
\text { removed }\end{array}$} & Maltose-1-14C & Glucose-1-14C & Lactose-1-14C \\
\cline { 2 - 5 } & & $\%$ dose/24 hours & \\
Sham & $48.3 \pm 7.7(4) *$ & $55.3 \pm 19.5(3)$ & $2.9 \pm 0.9(3)$ \\
Kidneys & $46.2 \pm 11.3(4)$ & $45.5 \pm 17.6(3)$ & $16.9 \pm 5.9(3)$ \\
Liver (70\%) & $50.1 \pm 9.2(5)$ & $43.9 \pm 4.7(3)$ & 2.4 \\
Small bowel & $45.0 \pm 2.7(3)$ & & $(1)$ \\
\hline
\end{tabular}

* Number of rats is given in parentheses.

gested that intravascular hydrolysis of circulating maltose, providing glucose for further metabolism, might explain its low urinary excretion. The blood glucose concentration was therefore measured in rats after iv infusion of $100 \mathrm{mg}$ of either giucose, lactose, sucrose, or maltose. After glucose infusion the expected rise in blood glucose was readily observed (Figure 4). A similar rise in blood glucose was noted only after maltose infusion.

\section{Discussion}

The minimal amounts of lactose, sucrose, and maltose that are absorbed intact after oral ingestion reflect the over-all efficiency of intestinal hydrolysis and, to a lesser extent, the relatively poor transport of unhydrolyzed disaccharide across the intestinal mucosa. Studies in man $(18,19)$ have shown that the rates of hydrolysis for sucrose and maltose are appreciably greater than the rate for lactose and that lactose hydrolysis is rate limiting for over-all lactose absorption.

Our studies show that after an oral load of lactose, more of the unhydrolyzed disaccharide is excreted in the urine than after comparable loading with sucrose or maltose. These observations are consistent with a less efficient hydrolysis of lactose resulting in increased absorption of the intact disaccharide. In normal mucosa an increasing level of activity exists between lactase, sucrase, and maltase $(3,20,21)$. The amount of unhydrolyzed disaccharide absorbed and excreted into the urine seems to be inversely proportional to the level of its disaccharidase activity. After oral loading, patients with untreated celiac disease excreted increased amounts of urinary lactose and sucrose, but not maltose. The previous demonstration that lactase activity is most severely reduced in

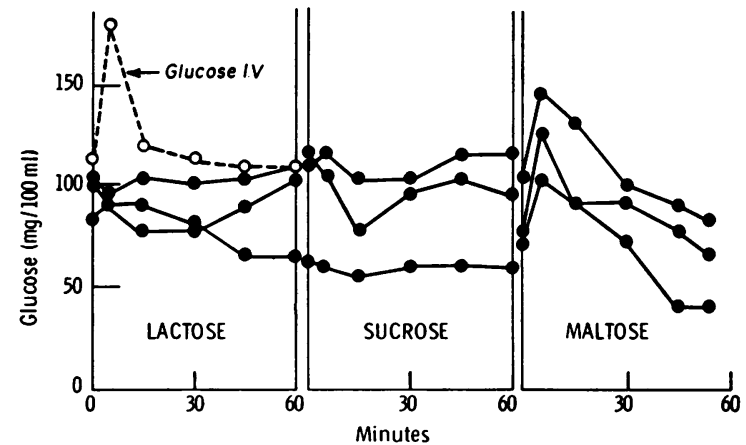

Fig. 4. Blood glucose concentration After IV INFUSION OF 100 MG OF LACTOSE, SUCROSE, OR MALTOSE IN THE RAT.

untreated celiac disease and maltase is least affected could explain this difference $(3,4)$. However, a difference in the metabolic fate of absorbed maltose may also be responsible for its low urinary excretion.

Previous studies in man and animals have shown that parenterally administered lactose or sucrose is rapidly excreted into the urine (22-25). Furthermore, the increase in blood lactose that occurs during lactation is associated with marked lactosuria (26). Unlike lactose and sucrose, the intravenously administered maltose was not followed by a significant excretion of the disaccharide in the urine of our subjects. Similar findings have been noted in the rat after ip injection of maltose (27). None of our adult subjects showed a rise in blood glucose after the iv administration of any of the disaccharides. In the rat, however, the rise in blood glucose noted only after maltose infusion suggests that some of the disaccharide is hydrolyzed intravascularly, particularly since rat serum possesses maltase activity.

The results of the experiments in which ${ }^{14} \mathrm{C}$ labeled disaccharides were administered to the rat indicate that injected maltose can be metabolized to $\mathrm{CO}_{2}$ almost as completely as glucose. On the other hand, lactose and sucrose are poorly oxidized to $\mathrm{CO}_{2}$ and are mainly excreted in the urine. Similar findings with lactose- $1-{ }^{14} \mathrm{C}$ have been reported by Carleton, Misler, and Roberts (28). Although all of the urinary isotope after injection of lactose- $1-{ }^{14} \mathrm{C}$ was identified chromatographically as lactose, studies performed with lactose-U $-{ }^{14} \mathrm{C}$ have shown that other radioactive peaks may be present in the urine (29). 
It is unlikely that the circulation of injected maltose to small bowel mucosa played a significant part in its over-all metabolism. One would expect on this basis that at least injected sucrose would also be metabolized. Furthermore, the removal of the small bowel did not affect the over-all metabolism of maltose to $\mathrm{CO}_{2}$. Several other organs also had maltase activity, but removal of these tissues did not significantly alter the oxidation of maltose to $\mathrm{CO}_{2}$. It therefore seems unlikely that a single tissue maltase was responsible for hydrolyzing circulating maltose. It is also possible that maltose may be metabolized via other pathways than through hydrolysis to glucose.

Previous reports of maltase activity in organs other than small bowel (30-34) have raised questions regarding its function. Since maltosyloligosaccharides have been isolated from rat liver (35, 36 ), an amylase-oligoglucosidase (maltase) pathway of glucose production from glycogen has been proposed (37), but thus far this hypothesis lacks convincing support (38). Hers (39) reported an absence of lysosomal acid maltase in tissues of patients with generalized glycogen storage disease and suggested that this enzyme deficiency is responsible for the accumulation of glycogen. Others have proposed that the maltosyloligosaccharides are glycogen precursors, but here also the evidence is conflicting (40-42).

In our experiments, maltase activity in rat kidney was greater than in any of the other organs studied with the exception of small bowel. The amount of ${ }^{14} \mathrm{CO}_{2}$ produced from maltose- $1-{ }^{14} \mathrm{C}$ compared with glucose $-1{ }^{14} \mathrm{C}$ by tissue slices was roughly proportional to the tissue maltase activity, i.e., kidney $>$ brain $>$ liver. It is also possible that, unlike liver (43), the kidney cell may be permeable to maltose. These findings suggest that maltase may have a more important metabolic role in the kidney than in liver.

\section{References}

1. Verzar, F., and E. J. McDougall. Absorption from the Intestine. London, Longmans, 1936.

2. Bickel, H. Mellituria, a paper chromatographic study. J. Pediat. 1961, 59, 641.

3. Plotkin, G. R., and K. J. Isselbacher. Secondary disaccharidase deficiency in adult celiac disease (nontropical sprue) and other malabsorption states. New Engl. J. Med. 1964, 271, 1033.
4. Weser, E., and M. H. Sleisenger. Lactosuria and lactase deficiency in adult celiac disease. Gastroenterology 1965, 48, 571.

5. Santini, R., Jr., E. Perez-Santiago, J. Martinez-de Jesus, and C. E. Butterworth, Jr. Evidence of increased intestinal absorption of molecular sucrose in sprue. Amer. J. dig. Dis. 1957, 2, 663.

6. Sheehy, T. W., and M. H. Floch. The Small Intestine: Its Functions and Diseases, 1st ed. New York, Harper and Row, 1964, p. 260.

7. Gryboski, J. D., W. R. Thayer, Jr., W. A. Gryboski, I. W. Gabrielson, and H. M. Spiro. A defect in disaccharide metabolism after gastrojejunostomy. New Engl. J. Med. 1963, 268, 78.

8. Gryboski, J. D., W. R. Thayer, Jr., I. W. Gabrielson, and H. M. Spiro. Disacchariduria in gastrointestinal disease. Gastroenterology 1963, 45, 633.

9. Kathan, R. H., J. Lumeng, and L. Williams. Quantitative determination of lactose in plasma following its oral administration (abstract). Clin. Res. 1965, $13,255$.

10. Salomon, L. L., and J. E. Johnson. Enzymatic microdetermination of glucose in blood and urine. Analyt. Chem. 1959, 31, 453.

11. Huggett, A. St. G., and D. A. Nixon. Use of glucose oxidase, peroxidase, and o-dianisidine in determination of blood and urinary glucose. Lancet 1957, 2, 368.

12. Nelson, N. A photometric adaptation of the Somogyi method for the determination of glucose. J. biol. Chem. 1944, 153, 375.

13. Fredrickson, D. S., and K. Ono. An improved technique for assay of $\mathrm{C}^{14} \mathrm{O}_{2}$ in expired air using the liquid scintillation counter. J. Lab. clin. Med. 1958, 51, 147.

14. Herberg, R. J. Channels ratio method of quench correction in liquid scintillation counting. Packard Technical Bulletin 1965, 15, 1.

15. Krebs, H. A., and K. Henseleit. Untersuchungen über die Harnstoffbildung im Tierkörper. HoppeSeylers Z. physiol. Chem. 1932, 210, 33.

16. Sols, A., and G. de la Fuente. Hexokinase and other enzymes of sugar metabolism in the intestine. Meth. med. Res. 1961, 9, 302.

17. Lowry, O. H., N. J. Rosebrough, A. L. Farr, and R. J. Randall. Protein measurement with the Folin phenol reagent. J. biol. Chem. 1951, 193, 265.

18. Gray, G. M., and F. J. Ingelfinger. Disaccharide absorption in normals and patients with tropical sprue (abstract). Clin. Res. 1965, 13, 254.

19. Gray, G. M., and F. J. Ingelfinger. Intestinal absorption of sucrose in man: the site of hydrolysis and absorption. J. clin. Invest. 1965, 44, 390.

20. Auricchio, S., A. Rubino, M. Landolt, G. Semenza, and A. Prader. Isolated intestinal lactase activity in the adult. Lancet 1963, 2, 324.

21. Dahlqvist, A., J. B. Hammond, R. K. Crane, J. V. Dunphy, and A. Littman. Intestinal lactase defi- 
ciency and lactose intolerance in adults. Gastroenterology 1963, 45, 488.

22. Deane, N., G. E. Schreiner, and J. V. Robertson. The velocity of distribution of sucrose between plasma and interstitial fluid, with reference to the use of sucrose for the measurement of extracellular fluid in man. J. clin. Invest. 1951, 30, 1463.

23. Deane, N., and H. W. Smith. Fate of inulin and sucrose in normal subjects as determined by a urine reinfusion technique. J. clin. Invest. 1955, 34, 681.

24. Dahlqvist, A., and D. L. Thomson. The digestion and absorption of lactose by the intact rat. Acta physiol. scand. 1964, 61, 20.

25. Dahlqvist, A., and D. L. Thomson. The digestion and absorption of sucrose by the intact rat. J. Physiol. (Lond.) 1963, 167, 193.

26. Watkins, O. Lactose metabolism in women. J. biol. Chem. 1928, 80, 33.

27. Dahlqvist, A., and D. L. Thomson. The digestion and absorption of maltose and trehalose by the intact rat. Acta physiol. scand. 1963, 59, 111.

28. Carleton, F. J., S. Misler, and H. R. Roberts. Comparison of the metabolism of $\mathrm{C}^{\mathbf{1 4}}$-labeled lactose, glucose, and galactose in rats. J. biol. Chem. 1955, 214, 427.

29. Carleton, F. J., and H. R. Roberts. Preliminary observations on the fate of intravenously administered lactose labelled with carbon-14. Nature (Lond.) 1959, 184, 1650.

30. Goldbarg, J. A., K. C. Tsou, S. H. Rutenburg, A. M. Rutenburg, and A. M. Seligman. A method for the colorimetric determination of $\alpha$-D-glucosidase with a chromogenic substrate. Arch. Biochem. 1958, 75, 435.

31. Rutenburg, A. M., J. A. Goldbarg, S. H. Rutenburg, and R. T. Lang. The histochemical demonstration of $\alpha$-D-glucosidase in mammalian tissues. J. Histochem. Cytochem. 1960, 8, 268.
32. Lejeune, N., D. Thinès-Sempoux, and H. G. Hers. Tissue fractionation studies. 16. Intracellular distribution and properties of $\alpha$-glucosidases in rat liver. Biochem. J. 1963, 86, 16.

33. Torres, H. N., and J. M. Olavarría. Liver $\alpha$-glucosidases. J. biol. Chem. 1964, 239, 2427.

34. Shibko, S., and A. L. Tappel. Rat-kidney lysosomes : isolation and properties. Biochem. J. 1965, 95, 731.

35. Fishman, W. H., and H. Sie. The presence of maltose, maltotriose, and maltotetraose in liver. J. Amer. chem. Soc. 1958, 80, 121.

36. Giri, K. V., A. Nagabhushanam, V. N. Nigam, and B. Belavadi. Synthesis of oligosaccharides from maltose by rat liver. Science 1955, 121, 898.

37. Rutter, W. J., and R. W. Brosemer. Glucose production by isolated rat liver cells. An amylaseoligoglucosidase pathway for glycogen breakdown. J. biol. Chem. 1961, 236, 1247.

38. Rutter, W. J., M. Arnold, R. W. Brosemer, and J. A. Miller. Liver amylase. II. Physiological role. J. biol. Chem. 1961, 236, 1259.

39. Hers, H. G. $\alpha$-Glucosidase deficiency in generalized glycogen-storage disease (Pompe's disease). Biochem. J. 1963, 86, 11.

40. Sie, H., J. Ashmore, R. Mahler, and W. H. Fishman. Liver glucosyl oligosaccharides and glycogen; carbon-14 dioxide experiments with hydrocortisone. Nature (Lond.) 1959, 184, 1380.

41. Olavarría, J. M. The metabolism of oligosaccharides. J. biol. Chem. 1960, 235, 3058.

42. Gödeken, O. G. R., R. Sandrus, and J. M. Olavarría. Metabolism of glycogen and maltosyl oligosaccharides. Biochim. biophys. Acta (Amst.) 1966, 117, 255.

43. Cahill, G. F., Jr., J. Ashmore, A. S. Earle, and S. Zottu. Glucose penetration into liver. Amer. J. Physiol. 1959, 192, 491. 